\title{
Autism Spectrum Disorder and Prenatal Risk Factors
}

\section{Otizm Spektrum Bozukluğu ve Prenatal Risk Faktörleri}

Semih Erden ${ }^{1}$,

Kevser Nalbant ${ }^{2}$,

${ }^{1}$ Konya Training and Research Hospital, Department of Child and Adolescent Psychiatry, Konya, Turkey

${ }^{2}$ Ordu State Hospital, Department of Child and Adolescent Psychiatry, Ordu, Turkey

Geliş Tarihi/Received: 01 February 2017 Kabul Tarihi/Accepted: 13 September 201

Address correspondence to: Semih Erden, Konya Training and Research Hospital,

Child and Adolescent Psychiatry Department, Konya, Turkey

e-mail: semihe84@gmail.com

\section{ORCID}

Semih Erden

https://orcid.org/0000-0002-7723-9584

\begin{abstract}
$\ddot{O z}$
Otizm spektrum bozukluğu, sosyal etkileşim ve iletişim bozukluğu ile kısıtlı ve tekrarlayıcı davranışlarla karakterize nörogelişimsel bozukluklardan biridir. Otizm yaklaşık 68 çocukta 1 görülmektedir. Son yıllarda yapılan çalışmalarda görülme sıkı̆̆ının arttığı bildirilmekte olup bu artışın bilgi ve farkındalığın artması ve tanı ölçütlerinin değişmesinden kaynaklandığı iddia edilmekle birlikte yapılan çalışmalarda çevresel faktörler ve bunların henüz bilinmeyen genetik bir takım etkenlerle ilişkisinin de bu artışa katkı sağladığ düşünülmektedir. Nörogelişimsel olarak önemli ve kırılgan bir dönem olan prenatal dönemde çocuğun maruz kaldığı çevresel faktörlerin otizm spektrum bozukluğu gelişmesi açısından risk etkeni olup olmadığının değerlendirilmesi önemlidir. Gebelik döneminde özellikle valproik asit, terbutalin, selektif serotonin geri alım inhibitörleri gibi ilaçlarla otizm spektrum bozukluğu arasında bir ilişki olduğu, bu dönemde ağır meta ve pestisite maruz kalmanın otizm spektrum bozukluğu riskini arttırdığı, yoğun sigara, alkol ve madde kullanımının nörogelişimsel süreci sekteye uğrattığı, gebelik döneminde geçirilen gestasyonel diyabet, otoimmun hastalıklar, enfeksiyonlar ve uzamış ateşin inflamatuar süreçler aracılığıyla otizm spektrum bozukluğu riskini artırabileceği bildirilmektedir. Göç, mevsimler ve gebelik döneminde maruz kalınan hava kirliliğininde risk artışına etkisi olduğu bildirilmiş ve daha fazla epidemiyolojik çalışmaya intiyaç olduğu vurgulanmıştır. Otizm spektrum bozukluğu ile ilişkili çevresel etkenlerin tanınması, anne adaylarının bu risk etkenleri ile ilgili bilgilendirilmesinin sağlanarak bu etkenlerden uzak durmaları veya bu etkenlerin elimine edilmesi ile otizm spektrum bozukluğu riskinin azaltılmasına yardımcı olabileceğinden bu alanda yapılan çalıșmaların derlenmesi ve risklerin ortaya konulması özellikle önemlidir. Bu gözden geçirmede son dönemde sayısı artan prenatal etkenler ile ilgili yapılan çalışmaların derlenerek bütüncül olarak ele almasının kolaylaştırılması hedeflemektedir.
\end{abstract}

Anahtar Kelimeler: Otizm, prenatal, çevresel, ağır metaller, hava kirliliği

\section{Abstract}

Autism spectrum disorder is a neuro-developmental disorder characterized by social interaction and communication, and restricted and repetitive behaviors. Autism is seen in nearly one of 68 children. The incidence is reported to increase, and the increase is suggested to arise from increased information, awareness and alterations in diagnostic criteria. However, environmental factors and their relationships to several unknown genetic factors are also considered to contribute to the increase. The assessment of whether environmental factors lead to risks for autism spectrum disorder in perinatal period, especially when children are exposed to these factors in a neurodevelopmentally important and fragile stage, is so important. It is reported that in pregnancy, there is an association between autism spectrum disorder and exposure to such drugs as valporic acid, terbutaline and Selective Seratonin Reuptake Inhibitors Exposure to heavy metals and pesticides increases the risk of autism spectrum disorder. Intense smoking, and alcohol consumption and drugsdisrupt neurodevelopmental process, Also, gestational diabetes may elavate the risk of autism spectrum disorder due to autoimmunal disorders, infections and inflammatory pocesse of prolonged fever. Migration, seasons and air pollution exposed in pregnancy are also reported to affect autism spectrum disorder risk. The awareness level between environmental factors and autism spectrum disorder should be increased among prospective mothers, and these mothers should be trained as to the risk factors. Because prospective mothers avoid these factors, or the elimination of these factors should be beneficial for reducing autism spectrum disorder risk, analyzing related studies and enlightening risk factors are especially important. Here, we aimed at revising recent studies related to prenatal factors from a holistic perspective.

Key words: Autism, prenatal, environmental, heavy metals, air pollution

\section{INTRODUCTION}

Autism Spectrum Disorder (ASD) is one of the neuro-developmental characterized by social communication and interaction deficits and repetitive, restricted patterns of behaviors (1). While the prevalence rates of ASD were 1-5/10000 in Diagnostic and statistical manual of mental disorders III (DSMIII) and 20/10000 in DSM-IV, an estimated prevalence of ASD was reported to be increased to $1 / 91$ or $1 / 68$ recent studies and continues to increase every year
Cite this article as: Erden S, Nalbant K. Autism Spectrum Disorder and Prenatal Risk Factors. Selcuk Med J 2019;35(4): 282-290
Disclosure: None of the authors has a financial interest in any of the products, devices, or drugs mentioned in this article. The research was not sponsored by an outside organization. All authors have agreed to allow full access to the primary data and to allow the journal to review the data if requested. 
$(2,3)$.

It was suggested that the dramatic increase in ASD incidence might be related with the changes in diagnostic criteria, knowledge and awareness (4). In a study, Fisch et al. reported that the increase of ASD prevalence was due to changes, epecially in diagnostic criteria (5). Several authors advocate the idea that polygenic and epistatic mechanisms play a part in the etiology of autism, and the effects of environmental factors on genetic factors can increase the risk of ASD $(6,7)$. Among environmental factors, the effects of primarily drugs whose neurotoxic effects are known, heavy metals, infectious agents, cigarette smoking and alcohol consumption were investigated in the etiology of autism, and the number of studies investigating the possible risk factors is continuing to increase.

The number of studies relating that environmental factors play a part in the etiology of ASD has been increasing. The aim of this review is to give a brief summary of the prenatal risk factors known to be associated with the etiology and pathogenesis of ASD.

\section{MATERIALS AND METHODS}

We reviewed previous reviews and studies to define ASD-related prenatal risk factors. We scanned the human studies in literature in English on PubMed until the 1st December, 2016. The research and scanning were designed to include the following terms, such as autism or "Autism Spectrum Disorder" or ASD or "Pervasive Developmental Disorder" or PDD and different searching terms for definite fields; and we scanned the literature by adding these terms to our list: "incidence", "prevalence", "thalidomide", "antiepileptic", "valproic acid", "misoprostol", "terbutalin", "antidepressants", "Selective Seratonin Reuptake Inhibitors", "SSRIs", "heavy metals", "mercury", "arsenic", "zinc", "cadmium", "organophosphate", "pesticides", "maternal diabetes mellitus", "gestational diabetes mellitus", "vitamin D", "25-hydroxyvitamin D", "alcohol", "ethanol", "preeclaampsia", "maternal infections" "advanced parental age", "assisted reproductive methods", "in vitro fertilization", "IVF", "intra-cytoplasmic sperm injection", "ICSI", "migration", "immigration", "maternal depresyon", "sasonality" and "air pollution". All studies obtained after scanning were investigated.

\section{Prenatal risk factors}

Due to several drugs taken in during the pregnancy period, the underlying mechanism of maternal drugt use during pregnancy still remains unclear (8).

Thalidomide is a well-known teratogenic agent causing many congenital dysmorphisms, such as limb defects and cardiovascular abnormalities. In a Sweden-centered study including a series of 100 cases with thalidomide embryopathy, it was reported that four cases met the symptoms of autism, and the risk of autism is fifty times higher patients with thalidomide embryopathy than general population (9).

Clinical trials show that exposure to valproic acid (VPA) in the first trimester of pregnancy is highly associated with having an autistic child (10). In fact, the association between VPA and autism is based on the increased frequency of autistic symptoms in children with fetal valproate syndrome. Exposure to in utero valproate was determined to increase the risk of autism up to 7 times, compared to those unexposed to any antiepileptic agent (11). In a more recent study investigating long-term effects of prenatal valproate exposure, a risk of developing autism or Asperger syndrome was found in $8.9 \%$ of the children exposed to VPA, and such an increase was not observed in other antiepileptic agents used as a monotherapy (12).

Misoprostol is one of the prostaglandin analogs used for medical miscarriages, leads to Mobius syndrome (13). Johansson et al. reported that among 25 Swedish cases with Mobius syndrome, six were diagnosed with autism, and the rate was even higher than general population (14). In a study investigating 23 patients between the ages of 1-11 years diagnosed with Mobius sequence, it was found that seven patients had ASD, and of seven children, four $(57.1 \%)$ were exposed to misoprostol in the first trimester (15). These authors reported the prevalence of ASD as around $26.1 \%$ in the patients with Mobius syndrome, and so the rate was higher than general population.

Terbutaline is a beta-2 adrenergic agonist (B2AR) used for the prophylaxis of asthma and preterm intervention. It was shown to be a teratogenic agent in animal studies (16). In dizygotic twins, increased concordance (relative risk=2.0) was observed for ASD, and an increase associated with exposure to terbutaline was found in male twins without an affected sibling (relative risk=4.4). In a study by Croen et al., although no relationship between B2AR exposure during pregnancy and autism risk was found, a relationship was stated to be present between terbutaline exposure $>2$ days during the 
third trimester and increased autism risk (17). In a recent case-control study where 5200 children with ASD were compared with 52000 children without ASD diagnosi, $3.7 \%$ of children with ASD and $2.9 \%$ of children in the control group were found to be exposed to B2AR during pregnancy. B2AR exposure during pregnancy was linked with the increased risk of ASD (18).

The most frequently used antidepressants for pregnant women are Selective Seratonin Reuptake Inhibitors (SSRIs), with reported rates of use in 3.3$4.5 \%$ of all women with pregnancy in Europe, and $3.8-5.0 \%$ in those in North America $(19,20)$. Various studies showed a possible relationship between exposure to SSRIs during pregnancy and increased ASD risk for children . In terms of exposure to SSRIs during pregnancy and ASD in children, a statistically significant positive correlation was reported in three out of six recent case-control studies, and the estimated relative risks in first trimester were given as 2.2, 2.34, and 2.91 in these studies. In addition to this, in a study where 5215 children with ASD and 52150 children as the control group born between 1997 and 2006 in Denmark were studied, ASD risk was found to double for children whose mothers used SSRIs during any phase of pregnancy (21). In their study, El Marroun et al. reported a statistically significant correlation between prenatal exposure to SSRIs, and the risk of pervasive developmental disorders (PDD) and high ASD scores (22). At the same time, prenatal depression symptoms were found to be related to PDD and lead to increased ASD scores, and the increase was found to be statistically significant for children with exposure to prenatal SSRIs. Boukhris et al. found no statistically significant increase between ASD risk and antidepressant use within the first trimester, while reporting a correlation between ASD risk and antidepressant use in second and/or third trimesters (31 exposed infants; adjusted hazard ratio, 1.87; $95 \% \mathrm{Cl}, 1.15-3.04)$ (23). On the other hand, the same authors found a statistically significant correlation between exposure to SSRIs in second and/or third trimesters, and increased ASD risk (22 exposed infants; adjusted hazard ratio, $2.17 ; 95 \% \mathrm{Cl}$, 1.20-3.93)

Maternal exposure to heavy metals such as mercury, lead, and cadmium was suggested to be related with mental retardation, lack of attention, learning difficulties and possibly neuro-developmental disorders. In their study by Kern et al. the levels of sulfhydryl reactive metals, i.e. arsenic, cadmium, and lead, were found to reduce in the hair of 45 children with ASD, compared with the control group (24). Kern et al. also suggested that children with ASD might have a difficulty in the secretion of these sulfhydryl reactive metals, and the accumulation of these metals might be a contributor to ASD symptoms. In a study consisting of 100 children with the diagnoses ranging from autism (severe) to ASD (mild) in terms of DSM-IV, Geier et al. investigated the relationship between maternal dental amalgams containing 50\% of mercury and the severity of ASD, and found a correlation between the severity of autism and the number of dental amalgams in mothers during the pregnancy (25).

Many animal studies showed that exposure to organophosphate pesticides at an early stage or intrauterine period affected neuro-developmental process (26). However, it is known that the number of human studies is limited. In a prospective cohort study performed by Rauh et al., exposure to high level of chlorpyrifos was reported to lead to higher CBCL scores in children with PDD (27). Eskenazi et al. reported that pre- and post-natal dialkylphosphate (DAP) metabolytes were associated to be twice higher with CBCL scores in children with PDD (Odds Ratio $(O R)=2.3)(28)$. Roberts et al. investigated the developmental risk of autism spectrum disorder (ASD) in children of mothers dwelling next to the regions where agricultural pesticides were used during the significant periods of their pregnancies, and found out in the study comparing 465 cases with 6975 control subjects that ASD risk was higher in children whose mothers lived close and were exposed to agricultural pesticides during the first trimester of the pregnancies $(O R=6.1)$ (29). The risk of ASD was shown to increase as the use, or poundage, of organochlorine increased, and to decrease with the distance to agricultural regions cultivated with pesticides. In the study by Shelton et al. it was reported that dwelling during pregnancy period close to the regions where organophosphates were used increased the risk of ASD at the rate of $60 \%$, exposure increased the risk in the third trimester (OR, 2.0), and the risk was higher during the second trimester in using chlorpyrifos (OR, 3.3) (30). We consider that further studies are needed due to the limited number of studies on the topic.

Both pregestational diabetes mellitus (PGDM) and gestational diabetes mellitus (GDM) are associated with many complications of pregnancy (31). In a metaanalysis where the likely association between maternal factors and ASD was investigated by Gardener et al. 
maternal GDM was reported to increase twofold the risk of autism (32). In the prospective cohort study by Lyall et al. GDM was found to be especially associated with a definite increase in the risk of ASD (OR= 1.76) (33). In another study where the association of obesity and diabetes mellitus (DM) with ASD, obesity in prepregnancy period and maternal DM were shown to be related to ASD; in the study, however, the risk of developing ASD was found to be significantly higher in mothers with obesity and PGDM (hazard ratio $3.91,95 \%$ confidence interval 1.76-8.68), compared with those with obesity and GDM (hazard ratio $3.04,95 \% \mathrm{Cl} 1.21-7.63$ ) (34). As opposed to this, Hultman et al. reported that no association was present between maternal DM and ASD (35). Also, in the meta-analysis where Guinchat et al. investigated the likely association between prenatal, perinatal and newborn factors, and ASD in 85 different studies, no powerful association was found between maternal DM and ASD (36). In another review and metaanalysis, however, maternal DM was reported to be significantly associated with the increase in the risk of ASD in offsprings. In a recent study where whether experiencing GDM increased the long-term risk of neuropsychiatric morbidity in offsprings was investigated, a possible association was reported to be present between experiencing utero-GDM and ASD (37). However, studies investigating these mechanisms and their findings are controversial and restricted associations.

Vitamin $D$ is the common ground of a group of sterols playing a part in the metabolisms of calcium and phosphorus (38). Main source of vitamin D is that 7-dehydrocholesterol is converted into pre-vitamin D3 in skin through ultraviolet B (UVB) radiation in the sunray, and vitamin $D$ is also obtained from nutrients at a lesser degree (39). Vitamin D deficiency has recently been related to ASD as a possible environmental risk factor, and a correlation has been observed between the frequency of autism and vitamin $D$ deficiency in countries with low level of vitamin D (40). In autistic children, 25-OHD serum levels were found to be significantly lower, compared to healthy children (41). A prospective study, even so, suggested that no association was present between maternal serum vitamin $D$ levels and autism at the 18th week of pregnancy (42). The role and metabolism of vitamin $D$ in women with pregnancy still remain an unclear entity. A study performed in USA suggested that ASD and UVB levels measured in the states where children were born were disproportionately correlated, and that children born in cloudy and wet states, such as Washington and California, were at twofold higher risk for autism, compared with those born in sunnier states (43). The frequency of autism was shown to be correlated with vitamin $D$ deficiency in dark-skinned mothers dwelling in the northern latitude band (44).

In a study, Schmit et al. investigated the effect of maternal folic acid intake on the risk of ASD and found that folic acid intake of mothers with normal children was significantly higher at the first month of pregnancy, compared with those with ASD children (45). It was reported that average folic acid intake of $600 \mu \mathrm{g}$ per day was associated with decreased level of ASD risk, and the risk decreased with the increase in folic acid. In a prospective Norwegian cohort study, Surén et al. investigated 85176 children, 270 of whom were diagnosed with ASD, and reported a significantly higher rate of autism in the children of mothers taking folic acid $400 \mu \mathrm{g}$ and more one month before and two months after the ititial of pregnancy, compared with those whose mothers were not exposed in utero to folic acid (46). Although there are several studies investigating the associations between autism and maternal folic acid intake, further studies are needed to enlighten the probable association of maternal folic acid deficiency with ASD.

The number of studies assessing the relationship between fish oils and autism is limited. Though there are two studies performed by Lyall $\mathrm{K}$ et al. and Surén et al. no association was found between the consumption of maternal fish or fish oils and autistic offsprings $(46,47)$. Both studies were performed self-reportedly, and we consider that further studies related to the topic are required.

Among the risks related to cigarette smoking during pregnancy period are birth defects, preterm birthsand lower birth weight (48). Hvidtjorn et al. reported that a great majority of mothers with ASD children smoke cigarettes (49). Ronald et al. also reported that the number of cigarettes smoked exhibited a marked and positive correlation with the features similar to those in 7- or 8-year-old autistic children (50). In a populationbased nested case-controlled study where 4019 patients with ASD and 16582 controls were assessed by Tran et al., PDD was found to be associated with continued maternal cigarette smoking during the whole of pregnancy, but not to be associated with smoking within the first trimester (51). Many studies have investigated whether exposure to second-hand cigarette smoke is associated with ASD; however, the findings suggested in these studies are inconsistent. 
Fetal alcohol syndrome (FAS) is a term used for a set of birth defects led by exposure to prenatal ethyl alcohol. Alcohol gives a harm to the fetal development from mild to severe, and the harm leads to lifetime physical, behavioral and cognitive disabilities (52). In a study, Nanson, reported six children diagnosed with autism in the group with the history of alcohol abuse and meeting the criteria of FAS during the pregnancy period (53). In a study by Aronson et al. in 24 children whose mothers had consumed a great amount of alcohol during the pregnancy period, Asperger syndrome was seen in two children, and autismlike behaviors not meeting the criteria of Asperger syndrome were observed in one child (54). Although there are studies reporting an association between ASD and a great amount of alcohol consumption, the findings of the studies correlating maternal average alcohol consumption with autism are restricted.

In a study investigating the association between obstetric variables and the severity of autism, hypertension, preecclampsia and common edema were found to be associated with the increase seen in communication and repetitive behavioral scores of the Autism Diagnostic Interview-Revised (ADI-R) (55). In a study performed by Buchmayer et al. preecclampsia was found to be associated with a $50 \%$ increase in the risk of developing an autistic disorder (56). Mann et al. reported that decreased birth weight contributed in part to the association between preecclampsia, ecclampsia and ASD (57). Finally, in a meta-analysis including 85 studies, no sufficient data were present in order to determine the risk factors between autism, PDD and preecclampsia (36). Despite the studies showing the association between preeclampsia and autism, further studies are required.

Maternal bacterial and viral infections experienced during the pregnancy period were reported to be an important risk factor for various neuropsychiatric disorders, including ASD (58). The risk of ASD is reported to increase in the children of mothers hospitalized due to infections during the pregnancy period (59). Especially viral infection-induced admissions in the first trimester $(\mathrm{HR}=3.0,95 \% \mathrm{Cl}$ : 1.3-7.2) and bacterial infection-induced admissions in the second trimester ( $\mathrm{HR}=1.4,95 \% \mathrm{Cl}$ : 1.1-1.9) were reported to increase such a riskand fever during the pregnancy period with ASD, it was reported that while no association was observed between influenza infections and ASD, a significant correlatşon was found between fever and ASD (60). In another study investigating the association between extensive infections, episodic fever and use of antibiotics, and ASD and infantile autism, experiencing influenza infections during the pregnancy period is reported to increase significantly the risk of ASD and infantile autism (HR = 2.3, 95\% Cl: 1.0-5.3) (61).

In literature, older parental age has been suggested as another environmental factor associated with ASD. In a meta-analysis performed by Gardener et al. older parental age was reported to be a risk factor as to the development of ASD (32). In the meta-analysis, it was reported that when maternal age was over 30 at the time of delivery, the risk of developing ASD increased at the rate of $27 \%$; when the age was 40 and over, the risk increased as $106 \%$, and a 5-year increase in maternal age led to a $7 \%$ increase at risk for ASD development. In the same meta-analysis, each 5-year increase in paternal age was found to cause an increased risk of $3.6 \%$ in pregnancy, and decreased paternal age, especially the fatherhood under 25 years of age, reduced the risk to $26 \%$ it was also asserted that old paternal age increased the risk due to de nova mutations pooling in spermatogonia or socio-cultural factors. On the other hand, older maternal age was suggested to lead to such problems as chromosomal abnormalities in oocytes and trinucleoid repetition and to be associated with increased obstetric complications, or increased risk of GDM due to old maternal age could also play a role for ASD. In light of present information, parental age, especially paternal age, is known to increase the risk of ASD; however, what mechanisms lead to the increase has yet to be understood precisely. It is obvious that additional studies should be performed on this topic, as well (32).

The findings presented by the studies investigating the association between the children born with the help of assisted reproductive technology (ART) and ASD are controversial. The methods of ART, such as ovulation induction, in vitro fertilization (IVF) and intracytoplasmic sperm injection (ICSI) were suggested to be potentially associated with ASD. In a study, Sandin et al reported that IVF performed using ICSI had a higher rate of risk for autism than IVF performed without ICSI (62). In another study, however, ICSI or conventional IVF was reported to have no effect on children's neural development (63). In a recent population-based study, it was reported that given ART, the incidence of autistic diagnosis was higher than conventional IVF, when ICSI was used, and that considering the reasons leading to infertility, the incidence was lower in those with unexplained 
infertility or tubal factor infertility. However, such a condition may be attributed to the fact that the cases with unexplained infertility had no other serious accompanying problems, and tubal factor infertility tends to be seen at a younger age (64). As understood from the findings of all these studies, further studies should be conducted to shed light on the association between ART and ASD.

Studies investigating the association between migration and autism demonstrate that if parents, especially mothers, are refugees or asylum seekers, migration will become a potential risk factor for ASD and the incidence of ASD in families immigrating to Scandinavian countries is higher, compared to native families (65). Migration is also considered to be associated with stress-induced epigenetic changes by leading to biopsychosocial stress. Performed for DNA procedures, also including methylation and histone deacetylation, epigenetic changes are changable hereditary modifications with the capacity of changing a gene expression in general. These epigenetic changes have been related to lower birth weight, congenital malformations and poor conditions experienced during the pregnancy period (66). In a recently performed study investigating the prevalence of autism and predicting factors among refugees, maternal migration has been emphasized to be a powerful predictor of autism (66). It is asserted that the reasons increasing the risk of autism in the children of refugee mothers may be associated with the marriages of disabled fathers to women from foreign countries because of lower opportunity of finding partners in the native country due to the disabilities, and that women born in other countries may not be vaccinated against infectious diseases common in the native country and may be relatively sensitive to infections; these entities are known as factors increasing the risk of autism (67).

Human neuro-development requires that neuronal components be organized to complex structural and functional networks. Increasing data suggest that prenatal maternal stress plays a part in accurately or mistakenly wiring of developing connectome. For this reason, stress-related symptoms are reported to be a risk actor for such neurodevelopmental disorders as ASD (68). Family maladaptation and stressful events experienced during the pregnancy period are asseted to be associated with the increased risk for the development of autism (69). In a study investigating the association between the prenatal environmental risk factors and autism, the history of depression experienced during the pregnancy period was suggested to increase the risk of autism (70). Another study also suggest that maternal stress/ depressive mood-state may be an etiological factor in autism (71). The association between stress and autism should be further investigated.

Among the studies investigating the association between seasonality and autism, as well as those suggesting an asscciation is present between both entities, there are also studies asserting vice versa (72). In a study investigating the association and performed by Zerbo et al. it is reported that the risk of autism increases among the women conceiving in winter months (December, January and February), and the pregnancy experienced in winter months leads to a higher risk of $6 \%$ for autism, compared to the pregnancy in the summer (73). Seasonalityis suggested to be effective at the early stages of pregnancy in terms of the photoperiod and amount of ultraviolet rays (74). It is also reported that there are also other seasonal confounding factors, such as temperature, altitude, infections and dieting, to be potentially effective on ultraviolet rays during the preconceptional period, but ultraviolet raysa re the most important constituent in seasonal rhythm (75). In another study assessing the effect of seasonality on autism, however, seasonality was asserted as an environmental factor even when genetic propensity was present (76). The association of seasonality with autism is suggested to be effective on the consumption of folic acid and vitamin $\mathrm{D}$ due to ultraviolet rays. While vitamin $D$ is synthesized in the presence of appropriate light, folic acid is harmed in the medium of light. There are also studies reporting that both vitamins are associated with autism. A study has drawn attention to the existence of an association between seasonality, vitamin D, folate and autism, and emphasized that such an association should be investigated in a more detailed way (75). In a meta-analysis performed by Gardener et al., an increase was observed in the risk of ASD in those born in March and August months, and the association was asserted to be associated with other viruses or infections to occur due to seasonal changes (6). Studies performed so far have shown that an association may be present between seasonality and autism; however, we consider that in order to enlighten the underlying effects, further studies are required.

Studies investigating the association between air pollution and autism point out that the constituents of air pollution may lead to oxidative stress and a 
systematic inflammatory response to be able to affect central nervous system (77). With the term of air pollution, the health-threatening constituents consisting of various gases and particules are implied. These constituents involve ozone (O3), nitric oxide (NO), traffic-originated industrial wastes, such as NO2, particular materials and polycyclic aromatic hydrocarbons, sprays and home-heated pollutant materials (PM), including PM10 (particules with median aerodynamic diameter smaller than $10 \mu \mathrm{m}$ ) and PM2.5 (tiny particules with median aerodynamic diameters smaller than $2.5 \mu \mathrm{m})(78)$. To the results of a meta-analysis including eight studies investigating the association between exposure to air pollution and autism, a significant association is reported to be present between the risk of developing autism and exposure to NO2, O3, PM2.5 and PM10 in an increasing way (79). A review investigating the antenatal effects on ASD has drawn attention to the positive association between ASD incidence and air pollution exposed during the pregnancy, especially in the third trimester (59).

Conclusively, despite the unknown etiology of autism, recent studies investigating the relationship between environmental factors in prenatal period and autism risk indicate that some drugs, such as VPA and SSRIs, high levels of exposure to ethanol during the pregnancy period, autoimmune diseases like DM, exposure to air pollution and other environmental effects, cigarette smoking, exposure to heavy metals and vitamin $\mathrm{D}$ deficiency are potential malicious factors associated with the increased risk of ASD. We consider that further studies are needed to reveal the environmental contribution to the genetic etiology of ASD and will provide an opportunity for the prevention of ASD.

Conflict of interest: Authors declare that there is no conflict of interest between the authors of the article.

Financial conflict of interest: Authors declare that they did not receive any financial support in this study.

Address correspondence to: Semih Erden, Konya Training and Research Hospital, Child and Adolescent Psychiatry Department, Konya, Turkey

Telephone: +905368526129

e-mail: semihe84@gmail.com

\section{REFERENCES}

1. Diagnostic and statistical manual of mental disorders (DSM). Washington DC: American Psychiatric Association, 1994:143-7.
2. Autism Developmental Disabilities Monitoring Network Surveillance Year Principal I, Centers for Disease C. Prevalence of autism spectrum disorders--Autism and Developmental Disabilities Monitoring Network, 14 sites, United States, 2008. MMWR Surveill Summ 2012;61(3):119.

3. Kogan MD, Blumberg SJ, Schieve LA, et al. Prevalence of parent-reported diagnosis of autism spectrum disorder among children in the US, 2007. Pediatrics 2009;124(5):1395-403.

4. Wing L, Potter D. The epidemiology of autistic spectrum disorders: Is the prevalence rising? Ment Retard Dev Disabil Res Rev 2002;8(3):151-61.

5. Fisch GS. Autism and epistemology III: Child development, behavioral stability, and reliability of measurement. Am J Med Genet A 2012;158A(5):969-79.

6. Gardener H, Spiegelman D, Buka SL. Perinatal and neonatal risk factors for autism: A comprehensive meta-analysis. Pediatrics 2011;128(2):344-55.

7. Hallmayer J, Cleveland S, Torres A, et al. Genetic heritability and shared environmental factors among twin pairs with autism. Arch Gen Psychiatry 2011;68(11):1095-102.

8. Bromley RL, Mawer G, Clayton-Smith J, et al. Autism spectrum disorders following in utero exposure to antiepileptic drugs. Neurology 2008;71(23):1923-4.

9. Stromland K, Nordin V, Miller M, et al. Autism in thalidomide embryopathy: A population study. Dev Med Child Neurol 1994;36(4):351-6.

10. Williams G, King J, Cunningham M, et al. Fetal valproate syndrome and autism: Additional evidence of an association. Dev Med Child Neurol 2001;43(3):202-6.

11. Bromley RL, Mawer GE, Briggs M, et al. The prevalence of neurodevelopmental disorders in children prenatally exposed to antiepileptic drugs. J Neurol Neurosurg Psychiatry 2013;84(6):637-43.

12. Rasalam $A D$, Hailey $\mathrm{H}$, Williams $\mathrm{JH}$, et al. Characteristics of fetal anticonvulsant syndrome associated autistic disorder. Dev Med Child Neurol 2005;47(8):551-5.

13. Gonzalez $\mathrm{CH}$, Marques-Dias MJ, Kim CA, et al. Congenital abnormalities in Brazilian children associated with misoprostol misuse in first trimester of pregnancy. Lancet 1998;351(9116):1624-7.

14. Johansson M, Wentz E, Fernell E, et al. Autistic spectrum disorders in Mobius sequence: a comprehensive study of 25 individuals. Dev Med Child Neurol 2001;43(5):338-45.

15. Bandim JM, Ventura LO, Miller MT, et al. Autism and Mobius sequence: An exploratory study of children in northeastern Brazil. Arq Neuropsiquiatr 2003;61(2A):181-5.

16. Connors SL, Crowell DE, Eberhart CG, et al. Beta2-adrenergic receptor activation and genetic polymorphisms in autism: Data from dizygotic twins. J Child Neurol 2005;20(11):87684.

17. Croen LA, Connors SL, Matevia M, et al. Prenatal exposure to beta2-adrenergic receptor agonists and risk of autism spectrum disorders. J Neurodev Disord 2011;3(4):307-15.

18. Gidaya NB, Lee BK, Burstyn I, et al. In utero Exposure to beta2-Adrenergic Receptor Agonist Drugs and Risk for Autism Spectrum Disorders. Pediatrics 2016;137(2):e20151316.

19. Cooper WO, Willy ME, Pont SJ, et al. Increasing use of antidepressants in pregnancy. Am J Obstet Gynecol 2007;196(6):544 e1-5.

20. Zoega $H$, Kieler H, Norgaard M, et al. Use of SSRI and SNRI Antidepressants during Pregnancy: A Population-Based 
Study from Denmark, Iceland, Norway and Sweden. PLoS One 2015;10(12):e0144474.

21. Gidaya NB, Lee BK, Burstyn I, et al. In utero exposure to selective serotonin reuptake inhibitors and risk for autism spectrum disorder. J Autism Dev Disord 2014;44(10):255867.

22. El Marroun $\mathrm{H}$, White TJ, van der Knaap NJ, et al. Prenatal exposure to selective serotonin reuptake inhibitors and social responsiveness symptoms of autism: population-based study of young children. Br J Psychiatry 2014;205(2):95-102.

23. Boukhris T, Sheehy O, Mottron L, et al. Antidepressant use during pregnancy and the risk of autism spectrum disorder in children. JAMA Pediatr 2016;170(2):117-24.

24. Kern JK, Grannemann BD, Trivedi MH, et al. Sulfhydrylreactive metals in autism. J Toxicol Environ Health $A$. 2007;70(8):715-21.

25. Geier DA, Kern JK, Geier MR. A prospective study of prenatal mercury exposure from maternal dental amalgams and autism severity. Acta Neurobiol Exp (Wars) 2009;69(2):18997.

26. Eskenazi B, Bradman A, Castorina R. Exposures of children to organophosphate pesticides and their potential adverse health effects. Environ Health Perspect 1999;107 Suppl 3:409-19.

27. Rauh VA, Garfinkel R, Perera FP, et al. Impact of prenatal chlorpyrifos exposure on neurodevelopment in the first 3 years of life among inner-city children. Pediatrics 2006;118(6):e1845-59.

28. Eskenazi B, Marks AR, Bradman A, et al. Organophosphate pesticide exposure and neurodevelopment in young Mexican-American children. Environ Health Perspect 2007;115(5):792-8.

29. Roberts EM, English PB, Grether JK, et al. Maternal residence near agricultural pesticide applications and autism spectrum disorders among children in the California Central Valley. Environ Health Perspect 2007;115(10):1482-9.

30. Shelton JF, Geraghty EM, Tancredi DJ, et al. Neurodevelopmental disorders and prenatal residential proximity to agricultural pesticides: The CHARGE study. Environ Health Perspect 2014;122(10):1103-9.

31. Berard J, Dufour P, Vinatier D, et al. Fetal macrosomia: Risk factors and outcome. A study of the outcome concerning 100 cases $>4500$ g. Eur J Obstet Gynecol Reprod Biol 1998;77(1):51-9.

32. Gardener H, Spiegelman D, Buka SL. Prenatal risk factors for autism: Comprehensive meta-analysis. $\mathrm{Br} \mathrm{J}$ Psychiatry 2009;195(1):7-14.

33. Lyall K, Pauls DL, Spiegelman D, et al. Pregnancy complications and obstetric suboptimality in association with autism spectrum disorders in children of the Nurses' Health Study II. Autism Res 2012;5(1):21-30.

34. Li M, Fallin MD, Riley A, et al. The association of maternal obesity and diabetes with autism and other developmental disabilities. Pediatrics 2016;137(2):e20152206.

35. Hultman CM, Sparen $P$, Cnattingius $S$. Perinatal risk factors for infantile autism. Epidemiology 2002;13(4):417-23.

36. Guinchat V, Thorsen P, Laurent C, et al. Pre-, peri- and neonatal risk factors for autism. Acta Obstet Gynecol Scand 2012;91(3):287-300.

37. Nahum Sacks K, Friger M, Shoham-Vardi I, et al. Prenatal exposure to gestational diabetes mellitus as an independent risk factor for long-term neuropsychiatric morbidity of the offspring. Am J Obstet Gynecol 2016;215(3):380 e1-7.

38. DeLuca HF. Overview of general physiologic features and functions of vitamin D. Am J Clin Nutr 2004;80(6 Suppl):1689S-96S.

39. Holick MF, MacLaughlin JA, Clark MB, et al. Photosynthesis of previtamin D3 in human skin and the physiologic consequences. Science 1980;210(4466):203-5.

40. Currenti SA. Understanding and determining the etiology of autism. Cell Mol Neurobiol 2010;30(2):161-71.

41. Mostafa GA, Al-Ayadhi LY. Reduced serum concentrations of 25-hydroxy vitamin D in children with autism: Relation to autoimmunity. J Neuroinflammation 2012;9:201.

42. Whitehouse AJ, Holt BJ, Serralha M, et al. Maternal vitamin $D$ levels and the autism phenotype among offspring. J Autism Dev Disord 2013;43(7):1495-504.

43. Waldman M, Nicholson S, Adilov N, et al. Autism prevalence and precipitation rates in California, Oregon, and Washington counties. Arch Pediatr Adolesc Med 2008;162(11):1026-34.

44. Patrick RP, Ames BN. Vitamin D hormone regulates serotonin synthesis. Part 1: relevance for autism. FASEB J 2014;28(6):2398-413.

45. Schmidt RJ, Tancredi DJ, Ozonoff S, et al. Maternal periconceptional folic acid intake and risk of autism spectrum disorders and developmental delay in the CHARGE (CHildhood Autism Risks from Genetics and Environment) case-control study. Am J Clin Nutr 2012;96(1):80-9.

46. Suren $P$, Roth $C$, Bresnahan $M$, et al. Association between maternal use of folic acid supplements and risk of autism spectrum disorders in children. JAMA 2013;309(6):570-7.

47. Lyall K, Munger KL, O'Reilly EJ, et al. Maternal dietary fat intake in association with autism spectrum disorders. Am J Epidemiol 2013;178(2):209-20.

48. Phelan S. Smoking cessation in pregnancy. Obstet Gynecol Clin North Am 2014;41(2):255-66.

49. Hvidtjorn D, Grove J, Schendel D, et al. Risk of autism spectrum disorders in children born after assisted conception: a population-based follow-up study. J Epidemiol Community Health 2011;65(6):497-502.

50. Ronald A, Happe F, Dworzynski K, et al. Exploring the relation between prenatal and neonatal complications and later autistic-like features in a representative community sample of twins. Child Dev 2010;81(1):166-82.

51. Tran PL, Lehti V, Lampi KM, et al. Smoking during pregnancy and risk of autism spectrum disorder in a Finnish National Birth Cohort. Paediatr Perinat Epidemiol 2013;27(3):266-74.

52. Morleo M, Woolfall K, Dedman D, et al. Under-reporting of foetal alcohol spectrum disorders: An analysis of hospital episode statistics. BMC Pediatr 2011;11:14.

53. Nanson JL. Autism in fetal alcohol syndrome: A report of six cases. Alcohol Clin Exp Res. 1992;16(3):558-65.

54. Aronson M, Hagberg B, Gillberg C. Attention deficits and autistic spectrum problems in children exposed to alcohol during gestation: A follow-up study. Dev Med Child Neurol 1997;39(9):583-7.

55. Wallace AE, Anderson GM, Dubrow R. Obstetric and parental psychiatric variables as potential predictors of autism severity. J Autism Dev Disord 2008;38(8):1542-54.

56. Buchmayer $S$, Johansson $S$, Johansson $A$, et al. Can association between preterm birth and autism be explained by maternal or neonatal morbidity? Pediatrics 2009;124(5):e817-25.

57. Mann JR, McDermott S, Bao H, et al. Pre-eclampsia, birth 
weight, and autism spectrum disorders. J Autism Dev Disord 2010;40(5):548-54.

58. Adams Waldorf KM, McAdams RM. Influence of infection during pregnancy on fetal development. Reproduction 2013;146(5):R151-62.

59. Ornoy A, Weinstein-Fudim L, Ergaz Z. Genetic syndromes, maternal diseases and antenatal factors associated with autism spectrum disorders (ASD). Front Neurosci 2016;10:316.

60. Zerbo O, IosifAM, Walker C, et al. Is maternal influenza or fever during pregnancy associated with autism or developmental delays? Results from the CHARGE (CHildhood Autism Risks from Genetics and Environment) study. J Autism Dev Disord 2013;43(1):25-33.

61. Atladottir HO, Henriksen TB, Schendel DE, et al. Autism after infection, febrile episodes, and antibioticuse during pregnancy: An exploratory study. Pediatrics 2012;130(6):e1447-54.

62. Sandin S, Nygren KG, Iliadou A, et al. Autism and mental retardation among offspring born after in vitro fertilization. JAMA 2013;310(1):75-84.

63. Bay B, Mortensen EL, Hvidtjorn D, et al. Fertility treatment and risk of childhood and adolescent mental disorders: Register based cohort study. BMJ 2013;347:f3978.

64. Kissin DM, Zhang Y, Boulet SL, et al. Association of assisted reproductive technology (ART) treatment and parental infertility diagnosis with autism in ART-conceived children. Hum Reprod 2015;30(2):454-65.

65. McEwen BS, Eiland L, Hunter RG, et al. Stress and anxiety: Structural plasticity and epigenetic regulation as a consequence of stress. Neuropharmacology 2012;62(1):312.

66. Crafa D, Warfa N. Maternal migration and autism risk: Systematic analysis. Int Rev Psychiatry 2015;27(1):64-71.

67. Lehti V, Hinkka-Yli-Salomaki S, Cheslack-Postava K, et al. The risk of childhood autism among second-generation migrants in Finland: A case-control study. BMC Pediatr 2013;13:171.

68. Scheinost D, Sinha R, Cross SN, et al. Does prenatal stress alter the developing connectome? Pediatr Res 2017;81(12):214-26.
69. Kinney DK, Munir KM, Crowley DJ, et al. Prenatal stress and risk for autism. Neurosci Biobehav Rev 2008;32(8):1519-32.

70. Gao L, Xi QQ, Wu J, et al. Association between prenatal environmental factors and child autism: A case control study in Tianjin, China. Biomed Environ Sci 2015;28(9):642-50.

71. Say GN, Karabekiroglu K, Babadagi Z, et al. Maternal stress and perinatal features in autism and attention deficit/ hyperactivity disorder. Pediatr Int 2016;58(4):265-9.

72. Landau EC, Cicchetti DV, KlinA, et al. Season of birth in autism: A fiction revisited. J Autism Dev Disord 1999;29(5):385-93.

73. Zerbo O, losif AM, Delwiche L, et al. Month of conception and risk of autism. Epidemiology 2011;22(4):469-75.

74. Lucock M, Glanville T, Yates Z, et al. Solar cycle predicts folate-sensitive neonatal genotypes at discrete phases of the first trimester of pregnancy: A novel folate-related human embryo loss hypothesis. Med Hypotheses 2012;79(2):210-5.

75. Lucock M, Leeming $R$. Autism, seasonality and the environmental perturbation of epigenome related vitamin levels. Med Hypotheses 2013;80(6):750-5.

76. Lee LC, Newschaffer CJ, Lessler JT, et al. Variation in season of birth in singleton and multiple births concordant for autism spectrum disorders. Paediatr Perinat Epidemiol 2008;22(2):172-9.

77. Hagberg $\mathrm{H}$, Mallard $\mathrm{C}$. Effect of inflammation on central nervous system development and vulnerability. Curr Opin Neurol 2005;18(2):117-23.

78. Viana M, Kuhlbusch T, Querol X, et al. Source apportionment of particulate matter in Europe: A review of methods and results. J Aerosol Sci 2008;39(10):827-49.

79. Flores-Pajot MC, Ofner M, Do MT, et al. Childhood autism spectrum disorders and exposure to nitrogen dioxide, and particulate matter air pollution: A review and meta-analysis. Environ Res 2016;151:763-76. 